\title{
Size Reduction Associated with Brachymesophalangia-5: A Possible Selective Advantage
}

\author{
STANLEY M. GARN, JERROLD M. NAGY, ANDREW K. POZNANSKI \\ AND MARY B. MCCANN \\ Center for Human Growth and Development and Department of Radiology, \\ The University of Michigan, Ann Arbor, Michigan and Center for \\ Disease Control, Atlanta, Georgia
}

KEY WORDS Brachymesophalangia-5 · Body size · Stature . Selection - Adaptive advantage · Bone - Nutrition * Growth.

\begin{abstract}
Subjects with brachymesophalangia-5 (the short middle segment trait of the fifth digit) are systematically reduced in the length of the second metacarpal and in stature, by approximately 0.5 standard deviations, in contrast with unaffected individuals or unaffected siblings of affected propositi. There is conclusive evidence for axial and appendicular length reduction in affected individuals, and the smaller body size associated with brachymesophalangia-5 may confer a selective advantage during growth under conditions of chronic caloric or protein-calorie malnutrition.
\end{abstract}

Brachymesophalangia-5, the short middle segment of the fifth digit, is a skeletal variant of considerable population interest (Garn, Fels and Israel, '67; Hertzog, '67; Garn, '71). It is often associated with clinodactyly-5 (the crooked little finger syndrome), camptodactyly-5 (the bent little finger syndrome) and cone-epiphysis-5 in younger subjects (Garn, Poznanski, Nagy and McCann, '72). Affected individuals may also show reduction of the proximal and distal segments of the fifth digit or reduction of the middle segments of the fourth and third digits (Garn, Fels and Israel, '67) indicating a "field" of digital reduction centering on mid-5. There is also some suspicion that individuals with brachymesophalangia-5 may also be reduced in long-bone length and in stature, suggesting a generalized size reduction associated with the trait.

To explore this possibility we have identified 248 individuals with brachymesophalangia-5 among the participants in the Ten-State Nutrition Survey of 1968-1970. Such individuals were characterized by marked reduction in the length of mid-5, by as much as 6 S.D. in adults of European ancestry, and averaging -3.3 S.D. in them. Expressed as a ratio, reduction of mid-5 was 4.6 S.D. relative to distal 5 , and 4.8 S.D. relative to proximal-5, con- firming differential size reduction of the middle segment of the fifth digit.

In the first step of the data analysis, the possibility of metacarpal reduction in affected individuals was examined by the simple sign test. To do this, the length of the second metacarpal (measured as diaphysis plus epiphysis) was individually compared with the norm or standard for sex, age and ancestry as ascertained in the ten-state survey. So compared, 229 individuals with brachymesophalangia-5 proved significantly shorter in the length of the second metacarpal than the appropriate individual average for age, sex and ancestry. To be exact, 54 of the 229 subjects were above average in length of the second metacarpal and 175 were below expectancy. The obtained proportions (54:175) were clearly different from the chance proportions (114.5:114.5). Reduction of the second metacarpal was particularly evident in affected females (26:110, chi-square $=51.9$ ) as compared with affected males $(28: 65$, chi-square $=14.7$ ). In both sexes, however, the trend toward metacarpal reduction in brachymesophalangia-5 was highly significant, the value of $p$ being less than 0.001 .

In the second step of the data analysis, the sign test was separately applied to stature (i.e., standing height) in 190 af- 
fected subjects for whom verifiable stature values were available. Of these nearly 200 individuals with brachymesophalangia-5, only 58 were above average in stature for age, sex, ancestry and state of origin, while 132 of them were below age-sexancestry-state expectancy. The proportion (58:132) differed significantly from the chance proportions (95:95) and the data confirmed stature reduction in association with brachymesophalangia-5. For stature, unlike length of the second metacarpal, there seems to be greater reduction in affected males (21:62, chi-square $=20.3)$ than in affected females (37:70, chisquare $=10.2$ ), though the trends show stature reduction was significant at $p=$ 0.01 or better in affected individuals of either sex.

Having confirmed both metacarpal size reduction (step 1) and statural reduction (step 2) in individuals with brachymesophalangia-5 against standards for age, sex and ancestry and even state of origin, the amount of such reduction then became of interest. Since two sexes, three ancestral groupings (European, African and Meso-American) and a wide range of ages were involved, data reduction and data analysis were simplified by the use of individual standard scores or Z-scores, each representing the difference between the age-sex-group norm $(\overline{\mathrm{X}})$ and the value (X) divided by the appropriate standard deviation (S.D.). So calculated, the mean length of the second metacarpal was 0.61 standard deviations or Z-scores below expectancy for 150 affected males and females of European ancestry, a reduction significant at better than $p=0.001$. For 22 affected subjects of largely-African ancestry, metacarpal 2 length reduction was 0.44 standard deviations below expectancy for age, sex and ancestry. Finally, 57 individuals of Meso-American ancestry characterized by brachymesophalangia-5 were also demonstrably reduced in the length of the second metacarpal and to a comparable degree, i.e., 0.42 standard deviation units. In short, individuals with brachymesophalangia-5 are characterized by metacarpal reduction approximating 0.5 standard deviation units below expectancy for their age and their sex and their ancestry.

The magnitude of stature reduction in brachymesophalangia-5 was similarly quantified, again using standard deviation units or Z-scores, corrected for age, sex, race and state of residence, as in table 1 . For 138 affected subjects of European ancestry, the magnitude of stature reduction was 0.45 standard deviation units. For 16 affected subjects of largely-African ancestry, the relative magnitude of stature reduction was very similar - i.e., 0.46 standard deviation units. Finally, 36 affected males and females of Meso-American ancestry exhibited an almost identical stature reduction of 0.47 standard deviation units $(p=0.01)$. For 190 subjects with brachymesophalangia-5, and with age, sex, race and stature definitely known, the mean stature reduction is nearly one half a standard deviation and significant at any reasonable level of confidence.

In contrast to the metacarpal length

TABLE 1

Length reduction in subjects with brachymesophalangia-5

\begin{tabular}{|c|c|c|c|c|c|}
\hline \multirow{2}{*}{$\begin{array}{l}\text { Geographical } \\
\text { ancestry }\end{array}$} & \multirow[b]{2}{*}{ Sex } & \multicolumn{2}{|c|}{ 2nd Metacarpal 1.} & \multicolumn{2}{|c|}{ Stature } \\
\hline & & No. & Mean Z & No. & Mean $\mathrm{Z}$ \\
\hline Europe & $\mathbf{M}$ & 59 & -0.53 & 56 & -0.52 \\
\hline Europe & F & 91 & -0.67 & 82 & -0.40 \\
\hline Europe & $M+F$ & 150 & -0.61 & 138 & -0.45 \\
\hline Africa & $\mathrm{M}$ & 11 & -0.21 & 8 & -0.27 \\
\hline Africa & $\mathbf{F}$ & 11 & -0.67 & 8 & -0.64 \\
\hline Africa & $M+F$ & 22 & -0.44 & 16 & -0.46 \\
\hline Meso-America & $\mathrm{M}$ & 23 & -0.26 & 19 & -0.55 \\
\hline Meso-America & $\mathrm{F}$ & 34 & -0.53 & 17 & -0.38 \\
\hline Meso-America & $M+F$ & 57 & -0.42 & 36 & -0.47 \\
\hline
\end{tabular}

Based upon age, sex and race-specific individual values of $Z$ for metacarpal length (epiphysis plus diaphysis) and stature (standing height).

All data from the 10-State Nutrition Survey of 1968-1970. 
reduction and the standing height or stature reduction characteristic of individuals with brachymesophalangia-5, unaffected siblings of affected subjects are not length reduced either in metacarpal length or in stature. This is best shown in a series of 86 unaffected siblings of White females affected with brachymesophalangia-5. These unaffected siblings were not systematically reduced in stature (45 above and 41 below age, sex, race and state of origin standards). Similarly, the unaffected siblings of affected females were not systematically reduced in metacarpal length ( 35 above and 46 below, chi-square 1.49). In neither case was there a meaningful influence of sex, i.e., there was no evidence that unaffected sisters of female propositi were more or less length reduced than unaffected brothers of female propositi.

These separate anthropometric and radiogrammetric evidences of size reduction in brachymesophalangia-5 have numerous implications for growth, for differential growth, for nutrition and for population genetics. To the student of human growth there is now clear indication that an apparently minor and seemingly trivial skeletal variant, characterized by length reduction and axial deviations, is but the "top of the iceberg" heralding systematic length reductions in the appendicular skeleton and apparently in the axial skeleton as well. To those concerned with nutritional surveys and population surveillance it is important to realize that a substantial proportion of individuals in some populations may be additionally short in association with brachymesophalangia-5 and clinodactyly-5. Certainly brachymesophalangia- 5 must be taken into account in Central American, South American and Asiatic populations where reduction of mid- 5 achieves a prevalence of $2 \%, 5 \%$ or higher in children surveyed. Affected subjects may be identified by radiography, and then deleted from the tabulations.

Up to now, there has been no reasonable explanation for the maintenance of brachymesophalangia-5 within populations, or the marked differences in the frequency of this trait between populations (cf. Garn, '71; Garn et al., '72). However, the marked association between brachy- mesophalangia-5 and statural reduction, amounting to half a standard deviation in infancy through adulthood, now suggests a possible adaptive advantage. Individuals so reduced in size may be presumed to enjoy lower caloric and nutrient requirements both for growth and for maintenance. This could give them a certain advantage under conditions of chronic caloric and protein malnutrition, or acute caloric and protein-calorie malnutrition (PCM). Under peak growth conditions, this advantage could amount to several hundred calories/day and several grams of protein.

Other workers have suggested a possible genetic advantage for smaller body size and consequently reduced caloric and nutrient needs under conditions of nutritional inadequacy (cf. Garn et al., '66; Frisancho, Garn and Ascoli; '70; Malcolm, '70; Graham and Adrianzen, '71: 696). Size reduction in association with brachymesophalangia-5 may constitute a type example, susceptible to direct test.

An exact test of this hypothesis is currently possible in those Central American and South American populations where the frequency of brachymesophalangia-5 is relatively high (Garn, Fels and Israel, '67; Garn, '71). Unfortunately, brachymesophalangia-5 is not easily diagnosed radiographically in infants, the population segment particularly at risk. On the other hand, morbidity in the three to six (pre-school) group is high in both rural and (migrant) urban groups and the possible selective advantage associated with brachymesophalangia-5 may be tested, both prospectively and retrospectively, in them. The direction of selection may also operate to reduce the brachy-5 trait in later life, as suggested by some of our adult data, in which case the advantage would then be transient and reversible.

\section{ACKNOWLEDGMENTS}

The research in this paper was supported by Contract HSM-110-69-22 with the Center for Disease Control, Atlanta, Georgia. We appreciate the assistance of Sam T. Sandusky in completing the review of affected cases and the editorial assistance of Shirley M. Garrett in the manuscript completion. 


\section{LITERATURE CITED}

Frisancho, A. R., S. M. Garn and W. Ascoli 1970 Unequal influence of low dietary intakes on skeletal maturation during childhood and adolescence. Am. J. Clin. Nutr., 23: 1220-1227.

Garn, S. M. 1971 Human Races. Third edition. Charles C Thomas, Springfield, Ill.

Garn, S. M., S. L. Fels and H. Israel 1967 Brachymesophalangia of digit five in ten populations. Am. J. Phys. Anthrop., 27: 205-210.

Garn, S. M., A. K. Poznanski, J. M. Nagy and M. B. McCann 1972 Independence of brachymesophalangia-5 from brachymesophalangia-5 with cone mid-5. Am. J. Phys. Anthrop., 36: 295-298.
Garn, S. M., C. G. Rohmann and M. A. Guzman 1966 Malnutrition and skeletal development in the pre-school child. In: Pre-School Child Mainutrition. National Academy of Sciences National Research Council, pp. 43-62.

Graham, G. G., and B. Adrianzen T. 1971 Growth, inheritance, and environment. Pediat. Res., 5: 691-697.

Hertzog, K. P. 1967 Shortened fifth medial phalanges. Am. J. Phys. Anthrop., 27: 113-117.

Malcolm, L. A. 1970 Growth and Development in New Guinea - A Study of the Bundi People of the Madang District. Monograph Series No. 1, Institute of Human Biology of Papua and New Guinea, Madang. 